\title{
Lapurdum
}

Euskal ikerketen aldizkaria | Revue d'études basques |

Revista de estudios vascos | Basque studies review

$7 \mid 2002$

Numéro VII

Mugerreko euskara : hurbilketa hat. Euskara batuaren eragina euskalkian, Euskal Ikastetetako Tesina-lana, zuznd. X. Videgain, Euskal Ikasketen Unibertsitateen arteko Saila, Pabe eta Aturri aldeko Unibertsitatea, 2001 (laburpena)

\section{Béatrice Sallaberry}

\section{(2) OpenEdition}

Journals

Édition électronique

URL : http://journals.openedition.org/lapurdum/1054

DOI : $10.4000 /$ lapurdum. 1054

ISSN : 1965-0655

Éditeur

IKER

Édition imprimée

Date de publication : 1 octobre 2002

Pagination : 353-355

ISBN : 2-86781-321-2

ISSN : $1273-3830$

Référence électronique

Béatrice Sallaberry, « Mugerreko euskara : hurbilketa hat. Euskara batuaren eragina euskalkian, Euskal Ikastetetako Tesina-lana, zuznd. X. Videgain, Euskal Ikasketen Unibertsitateen arteko Saila, Pabe eta Aturri aldeko Unibertsitatea, 2001 (laburpena) », Lapurdum [Linean], 7 | 2002, Sarean emana----an 01 juin 2009, kontsultatu 19 avril 2019. URL : http://journals.openedition.org/lapurdum/1054 ; DOI : 10.4000/lapurdum. 1054 


\section{Béatrice SALABERRY}

\section{Mugerreko euskara: hurbilketa bat. Euskara batuaren eragina euskalkian, Euskal Ikastetetako Tesina-lana, zuznd. X. Videgain, Euskal Ikasketen Unibertsitateen arteko Saila, Pabe eta Aturri aldeko Unibertsitatea, 2001 (laburpena)}

2001-ko otsailean UNESCO erakundeak txosten bat plazaratzen zuen, munduan zehar arriskuan diren hizkuntzak zein ziren seinalatuz. Honen aipatzea xeheki luzeegi liteke bainan gure kasuan kezkagarria zaiguna honako hau da: euskara ere agertzen dela hizkuntza horien artean. Euskara egoera larrian dela ezin da ukatu, bainan zailagoa da jakitea zehazki zertan den finki hunkitua.

Azken denboraldi hauetan argi da hizkuntzen bilakaeraren eta hizkuntzen heriotzaren ${ }^{4}$ inguruko lanak ez direla eskas. Arriskuan diren hizkuntzen kasuan gehienetan azterketa soziolinguistikoak egiten dira. Ikertzen da zein diren hizkuntzaren desagertzearen ondorioak, eta diglosiaren ${ }^{5}$ ondorioak pertsonengan, norberak nola bizi duen hizkuntza gutxitu baten mintzatzea, edo ezin erabilia izana. Beste aztermolde bat izan liteke hizkuntza bera zertara doan ikertzea, zein diren hizkuntzak erakusten dituen sakoneko aldaketak, hots azterketa linguistikoa.

Azken honek bereziki gaitu interesatzen. Zertara doa euskara? Zein dira pairatzen edo bizi dituen aldaketak? Nun, noiz eta nola aldatzen da? Zein dira erdara ezberdinen eraginak eta euskara batuak ba ote du ondoriorik euskalkietan? Hizkuntzaren oinarriak andeatuak ote dira, ala sistema oraindik zaintzen ote da? Erran ote dezakegu euskarak segitzen duela osasun onean? Ala gure arbasoek mintzatzen zutenetik erabat aldatu dela eta beste hizkuntza batera goazela? Eta beste hainbeste galderek erantzunik gabe diraute.

Hainbat galderari erantzuteko lana ez baita egunetik biharamunekoa, pentsatu genuen hastea toki finko batean eta bi belaunaldiren hizkeren konparaketa egitea, jakinez bi belaunaldi hauen bizimoldeak eta komunikazio eremuak oso ezberdinak izanen zirela. lanaren eremua eta gaia mugatu beharrez, bereziki aditzaren morfologia eta erabilera begiratzea erabaki genuen.. Kasu honetan, partikulazki, Mugerrreko herriaren kasua dugu aztergai.

Lan honen bukaeran agertu zaizkigun ondorioak aski pizu dira.

Nabaritu ditugun aldaketak bi sailetan bana daitezke. Lehenak izan litezke morfologia mailako aldaketak, adizkiak eratzen, eraikitzen diren moldeari begira. Besteak aldiz, erabilera mailakoak, adizki ezberdinak noiz eta nola erabiliak diren.

4 Hizkuntza guziak, izateen moldean, pizten eta aldatuz, joaten dira, euskararen kasuan, proto euskaratik gaurregungo euskalkietara bezala, baita, zorigaitzez, egun batez desagertzen, edo aldakia(k) besterik ez uzten.

${ }^{5}$ Diglosia deitu fenomenoa aski arrunta izaten da eta hizkuntzen arteko borroka bat adierazten du, nun hizkuntzek gehietasuna bilatzen baitute. Bata hizkuntza nagusia edo goi mailakoa izaten da eta bestea hizkuntza menderatua edo peko mailakoa. Euskara egoera horretan dugu aspaldidanik, erdara ezberdinez inguratua eta menderatua denez geroz. Gainera, euskalkiak edo tokian tokiko aldakiak, nolazpait egoera horretan dira ere euskara batuari begira, hizkuntza arautua delarik goi mailakoa bezalakoa konsideratua jende anitzen kasuan, eta tokiko hizkerak, biziki maitatuak izanik ere askotan gutxituak hiztunengandik. 
Morfologiaren aldetik, argi ikusten dira da euskalkiaren baztertzea eta euskara batuaren sartzea. Hau da, eguneroko bizian duen tokiaren bidez baita euskaldun berrien bitartez, euskaldun zaharrak ere, sortzez hiztun direnak, eraginak direla beren mintzatzeko moldean. Euskara batua elkarrizketan zehar entzun daiteke tarteka eta molde arras naturalean, ezezko erantzunetan ${ }^{6}$ agertzen direlarik bertako formak.

Bertako formak, endemikoak ${ }^{7}$ deitzen ditugunak, baztertzen dira edo desagertzen. Batzutan, lekukoek ezezko erantzunetan aipatuko dituzte bertako formak, entzunak diren formen moldera, gurasoek edo adinekoek erabiliak. Beraiek aldiz ez dituzte erabiltzen. Edo, ez dituztela sekulan entzun erranen dute ere

Gainera, adizki formak ez dira gehiago hainbesteraino baxe nafartarrezko formak, askotan aurkituko direlarik ibrido ${ }^{8}$ dei ditzakegunak, erran nahi baita erabili forma erdi bidean dela tokiko, euskalkiko forma eta euskara batuko formaren artean. Lekukoek ez dituzte ez arras tokiko formak erabiltzen bainan ez eta ere arras euskara batuko formak, bien arteko nahasketa bat gelditzen da beraz momentukotz. Aurrerizten ahal da gauzak legunduz eta berdinduz doazen heinean, aldaketa osatuko dela ondoko belaunaldietan.

Hauek izan daitezke inguruetako aldakien eraginaren ondorioak eta ez bakarrik euskara batuarenak. Halere euskara batuaren presentzia hemen gehien bat zor zaie belaunaldien arteko helarazte ezari eta erabilpen murritzari, hizkuntza erabiltzean gertatzen diren eskasak betetzen dituelarik, erran nahi baita hizkuntzaz ez direla osoki jabetzen haurrean eta ordaintzen dutela ahal duten neurrian. Nolazpait hauek euskararen eguneroko bizitik desagertzearen, frantsesaren nagusitza eta, orokorkiago, hizkuntz politika ez egokiaren ondorio zuzenak direnean.

Erabileraren aldetik harrigarriena da zein heinetaraino murriztu den erabiliak diren adizkien kopurua, aditz laguntzaile nola aditz trinkoen kasuan.

Aditz laguntzaile parrasta bat ez da erabilia. Hauetarik batzuk ezagutzen dituztela agertu da ezezko erantzunetan, bainan kasu gutitan. Hau da ${ }^{*}$ edin eta ${ }^{*}$ ezan aditz laguntzaileen kasua ${ }^{9}$. Subjuntibozko formak erabili ordez aurkituko dira moldeak, nolazpait, zailtasunaren zeharkatzeko, nominalizioaren bidez adieraziko dute nahi dutena edo, agintearen kasuan, aditz oin bakarrarekin. Hainbat molde garatzen dituzte zailtasunei aurregiteko, ikasi ez dituzten edo sekulan entzun ez dituzten formen ordezkatzeko.

Bestalde aipagarria da ere aditz laguntzaileko partaideen kontua. Izan ere *nor nori nork moldeko aditzak errexkI bilakatuko dira nor nork formakoak eta nor nori adizkiak ez dira erabiliak.

Aditz trinkoak, neurri batean erabiliak baldin baziren duela hogoi bat urte, gaurregun aldiz arras desagertu dira, salbuespen direlarik ibili, joan eta etorri bezalako aditzak, aski arruntak direnak, eta forma sinpleenetan, indikatiboko orainean eta nor pertsona bakarreko formetan : dabila, banoa.

${ }^{6}$ Ezezko erantzunak elkarrizketatuek eman erantzunak dira bainan elkarrizketaren bigarren fase batean. Goaitatu erantzuna edo tokikoa ez dutenean ematen, guk proposatzen diegu eta haiek erranen dute ea ezagutzen eta erabiltzen dituzten ala ez.

${ }^{7}$ Endemikoak deitzen ditugunak, tokikoak dira eta horkoak bakarrik. Beste euskalkietan aurkitzen ez direnak eta aldakiaren lekuko direlarik.

8 Aurkitu ditugun forma berezi hauek horrela deitu ditugu, izen honek duelako direna hobekien adierazten. Gure ustez, bi formen arteko nahasketa baitira eta seguraski batetik besterako bidean baitoaz.

9 *Edun eta *izan laguntzaileak osoki erabiliak dira, guti edo aski. 
Hots, adizkien kopuru haundia da ahanzten edo zeharkatzen dena. Izugarriko pobretzea adierazten du honek, uste izateko da da hiztegi eta sintaxiaren aldetik ber gauza gertatzen dela ere. Hauek ere zor dizkiogu dudarik gabe hizkuntzaren erabilpen mugatuari, hortik etortzen denean ezagupen edo menperatze arina.

Azterketaren ondorioei dagokionez, hauek dira aldaketa larrienak.

Ondorio hauetaz gain, baliteke ere hiztegiaren aldetik erdarakada ihaurri sartzea, hau ez zenez gure gaia, ez gara horretan luzatuko.

Bestalde, tokian berean eta hizkuntzaz bestalde, beste hainbeste elementu arranguragarri agertu zitzaizkigun eta gauzatxo bat azpimarratu nahi genuke. Oroz gainetik, lekukoen bilatzea ez zen errexa izan. Euskaldun zahar guti dagoelako orain herri horretan. Kontsidera dezakegu mugertarren \%20a euskalduna dela eta horien artean gazte guti, baita euskaldun berri andana bat ere. Gure ustez, lekukorik adierazgarrienak hautatu genituen, hautua dorpea izan arren. Egia da jatorriz biztanleen gehiena kanpotarra dela, bainan tokiko jendea ez da urria. Halere, hau dugu ondorioetarik bat baita, dudarik gabe, gertakaririk kezkagarriena: euskaldun zaharren presentziaren eza, deseuskalduntze aintzinatua. Horrek erran nahi luke ez dela gehiago euskara belaunaldi batetik bestera heltzen eta euskara dakiten jendeek ikasi behar izan dutela.

Ondorioztapen hauek egin ditugu azaleko azterketa bat eramanik, labur biltzeko errextea, baturatzea eta pobretzea. Erran dezakegu euskarak ere larriki erantzuten diola hitzen ekonomiari. Erdararen eragina eta euskara batuarenak ez dira dudazkoak. Hauek oro gertatzen dira lekukoak ez direlakotz gai euskara zuzen eta molde erosoan erabiltzeko, erdararen presentzia gehiegiarengatik, baita euskararen prestigio eta ezagupen ezagatik. Pentsatzekoa da gauzak ez doazela hobetuz.

Bainan seguraski interesgarriagoa baizik ez liteke ber motako ikerketa bat eramatea sintaxia, lexikoa, morfosintaxia, hots hizkuntzaren alderdi guziak ikertuz. Erdarak egiazki zein heinetarainoko eragina duen aurkitzeko parada liteke. Nahiz eta lan hori oraindik egitekoa gelditzen den, pentsatzekoa da maila hortan ere hainbat aldaketa ikus ditzakegula. Ikerketa honek, sakonagoa izanez gero, aukera emanen luke neurtzeko hizkuntzaren sistema zenbatetaraino kaltetua den. Jadanik, ikerketa honen ondotik, aurreikusten badira hainbat gauza, ez da deus segurrik eta, sustut, ez da deus zehazki neurturik oraindik.

Gure ustetan, nahiz eta indar haundi eta preziagarriak eginak izan erakunde eta elkarte ezberdinenganik, argi da ez dela aski euskararen menperatze eta erabileraren hobetzeko eta emendatzeko. Ikerketa honek bakarrik erakusten baldin baditu horrelako ondorioak, errealitatea ilunagoa baizik ez daiteke izan. Hizkuntzaren sanotzeko, orain arte egina denaz gain, gaurregungo indarrak baino gehiagoko zerbait beharko delakoan ez da duda izaterik. 